\title{
Budaya Awal Holosen Di Gunung Sewu
}

\section{Harry Truman Simanjuntak}

Keywords: karst, cave, settlement, chronology, culture, prehistory

\section{How to Cite:}

Simanjuntak, H. T. (1999). Budaya Awal Holosen Di Gunung Sewu. Berkala Arkeologi, 19(1), 1-20. https://doi.org/10.30883/jba.v19i1.789

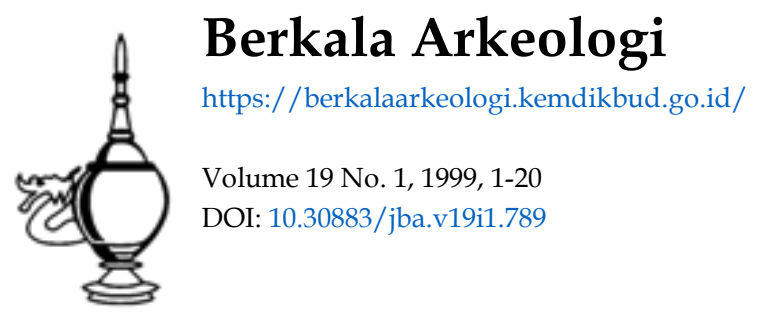

\section{c) (i) (5)}

This work is licensed under a Creative Commons Attribution-NonCommercial-ShareAlike 4.0 International License. 


\title{
BUDAYA AWAL HOLOSEN DI GUNUNG SEWU*
}

\author{
Truman Simanjuntak \\ (Pusat Penelitian Arkeologi Nasional)
}

\section{Pendahuluan}

Gunung Sewu sebagai bagian dari Pegunungan Selatan Jawa meliputi wilayah yang luas, memanjang sekitar $80 \mathrm{~km}$ dari Teluk Pacitan di sebelah timur hingga Kali Oyo (Wonosari) di sebelah barat dan melebar sekitar $20 \mathrm{~km}$ dari pantai Samudera Hindia ke arah utara, pada koordinat $3^{0} 48^{\prime} 00^{\prime \prime}-4^{0} 17^{\prime} 35^{\prime \prime}$ BT (dari Jakarta) dan antara $7^{0} 54^{\prime} 49^{\prime \prime}-8^{0} 13^{\prime} 23^{\prime \prime}$ LS. Secara administratif terbagi dalam 3 wilayah propinsi, yaitu Propinsi Jawa Timur (Kab. Pacitan), Propinsi Jawa Tengah (Kab. Wonogiri) dan Propinsi Daerah Istimewa Yogyakarta (Kab. Wonosari). Daerah ini tersusun oleh batu gamping koral yang berumur Miosen dan mengalami pengangkatan pada kala Plestosen Tengah (Semah et.al, 1990). Melalui proses crosi dan karstifikasi tercipta ribuan bukit karst berbentuk setengah bulatan atau kerucut, dipengaruhi komposisi gamping pembentuknya. Penamaan "Gunung Sewu" atau Pegunungan Seribu sebetulnya lebih tepat sebagai "bukit Sewu" (bukit seribu), karena ketinggiannya tidak melebihi $80 \mathrm{~m}$ dari lembah atau sekitar $450 \mathrm{~m}$ dari permukaan laut. Diperkirakan sekitar 40.000 bukit terdapat di seluruh wilayah Gunung Sewu dengan yang terpadat di bagian timur (daerah Kab. Pacitan), ratata mencapai 30 bukit $/ \mathrm{km}^{2}$ (Bartstra, 1976). Di antara bukti-bukti karst terdapat lembah dan dataran sempit serta di beberapa tempat terdapat cekungan yang digenangi air (telaga).

Keberadaan batu gamping yang dominan di satu pihak memungkinkan terbentuknya gua-gua dan ceruk di lereng-lereng bukti serta sungai-sungai yang melewati bawah tanah. Bagian timur memiliki lebih banyak gua dibanding bagian barat. Di bagian ini pula banyak ditemukan sungai-sungai bawah tanah yang masuk-keluar perbukitan hingga bermuara di Sanudra Hindia. Di pihak lain dominasi perbukitan gamping mengakibatkan daerah ini tergolong kering dan gersang. Pada musim kemarau, sungai-sungai yang umumnya bermuara ke Samudra Hindia kering. Beberapa sungai melintasi Gunung Sewu, antara lain Kali Baksoka yang merupakan situs paleolitik, berhulu di Gunung Batok; Kali Janti berhulu di daerah Pringkuku; Kali Lanang yang berhulu di daerah Jembang dan bermuara di Bengawan Solo; Kali Oyo yang berhulu di Gunung Kukusan. Sungai Bengawan Solo purba yang terdapat di daerah Giriwoyo dulunya mengalir ke selatan, namun melalui proses pengangkatan dan penyesaran bongkah pada Plestosen Tengah, arah aliran sungai beralih ke utara (Bemmelen, 1949).

Pemah disajikan pada Evaluasi Hasil Penelitian Arkeologi di Cipayung, 16--20 Februar 1998. 
Di antara puluhan gua dan ceruk yang tersebar di wilayah ini, Song Keplek dan gua Braholo merupakan prioritas yang diteliti secara intensif oleh Bidang Prasejarah, Puslit Arkenas. Beberapa gua lainnya, seperti Song Terus, Song Gupuh, Song Agung, gua Gunung Gede, sedang dalam penelitian, tetapi dalam rangka kerja sama dengan pihak luar negeri. Pemilihan kedua gua ini didasarkan pada temuan permukaan yang relatif lebih banyak dibanding gua lainnya, serta kondisi gua dan lingkungannya yang ideal untuk hunian. Song Keplek yang terletak di desa Punung, Pacitan, mewakili bagian timur dan gua Braholo di desa Semugih, Wonosari, mewakili bagian barat Gunung Sewu.

Song Keplek merupakan gua tebing pada koordinat $4^{0} 11^{\prime} 39^{\prime \prime}$ BT dan $8^{0} 7$ '35"LS. Ketinggian $348 \mathrm{~m}$ di atas muka laut dan $5 \mathrm{~m}$ dari dataran. Gua menghadap ke tenggara (N $110^{\circ} \mathrm{E} 119^{\circ}$ ), memiliki ruangan seluas $\pm 224 \mathrm{~cm}^{2}$ (gambar 1). Lantai gua tergolong datar dan ruangan melebar ke samping $(21 \mathrm{~m})$ dengan sirkulasi udara dan intensitas sinar yang baik. Ruang bagian belakang terisi oleh blok-blok gamping yang merupakan runtuhan dari atap gua. Batuan penyusun gua ini adalah batu gamping kristalin segar berwarna putih susu dan lapuk berwarna putih kecoklatan (Intan, 1996). Gua Braholo terletak di tebing sebuah perbukitan karst pada koordinat $35^{\circ} 6{ }^{\prime} 27^{\prime \prime}$ BT dan $8^{\circ} 4^{\prime} 10^{\prime \prime}$ LS dengan ketinggian 352 meter di atas muka laut. Gua menghadap ke arah barat daya: pintu masuk sangat lebar $(39 \mathrm{~m})$ dan langit-langit cukup tinggi $(15$ $\mathrm{m}$ ), sehingga memungkinkan sirkulasi udara dan intensitas sinar yang baik di dalam gua (gambar 2). Ruangan di dalam gua tergolong luas, yaitu sekitar $1248 \mathrm{~m}^{2}$ dengan kemiringan lantai $16 \mathrm{ke}$ arah timur laut (bagian dalam). Batuan penyusun gua adalah gamping (Intan, 1997).

Penelitian yang dilaksanakan selama ini, baik melalui program murni bidang, kerjasama dengan Perancis dan bantuan Toyota Foundation, telah memperoleh berbagai kemajuan dalam upaya memahami prasejarah Gunung Sewu (Simanjuntak, 1996). Berbagai masalah telah dapat dipecahkan dan semuanya berkaitan dengan proses hunian dan eksploitasi daerah ini, sejak kehadirannya hingga menjelang masa sejarah. Makalah ini mencoba membicarakan secara khusus budaya yang berkembang sejak awal Holosen hingga menjelang neolitik, atau yang secara umum disebut mesolitik. Bahasan akan didasarkan pada hasil penelitian di gua Braholo dan Song Keplek dengan beberapa data pendukung dari gua-gua lainnya.

\section{Kronologi perkembangan budaya}

Ekskavasi yang telah dilaksanakan selama ini telah berhasil membuka beberapa kotak berukuran 2 × 2 meter: 8 kotak di Song Keplek dan 5 kotak di Gua Braholo (Retno Handini, 1996; 1997). Lapisan anthropic masih terus berlanjut hingga kedalaman 
terakhir, sehingga ekskavasi di kedua gua ini masih harus dilanjutkan hingga mencapai lapisan steril. Hasil pertanggalan melalui metode radio carbon sejauh ini telah mencakup rentang waktu hunian gua sejak awal Holosen atau antara 12.000 hingga 4500 tahun yang lalu. Sebelum dan sesudah rentang waktu tersebut masih terdapat lapisan budaya yang belum dipertanggal. Di bagian atas merupakan lapisan neolitik yang diperkirakan mulai berkembang sekitar 4.000 tahun yang lalu, dicirikan oleh keberadaan kereweng dan calon beliung persegi. Masih terdapatnya alat-alat serpih dari rijang pada lapisan ini merupakan tradisi yang masih dipertahankan, walaupun sudah mengenal teknologi baru. Melihat lapisan pengandung temuan tersebut tidak tebal dan terbatas pada lapisan teratas, maka dapat diperkirakan bahwa budaya ini tidak lama berkembang di dalam gua. Keberadaan puluhan situs "atélier" neolitik di lereng bukit dan dataran terbuka mengindikasikan pusat kegiatan budaya ini kemudian beralih dari gua ke dataran terbu

Lapisan budaya paling dalam hingga ekskavasi terakhir diduga telah berumur Plestosen. Di Song Keplek lapisan ini dicirikan oleh lempung abu-abu yang terlineasi oleh karbonat, sebagai indikasi iklim lembab dan basah. Tinggalan pada lapisan ini berupa alat-alat batu yang cenderung lebih besar dengan pengerjaan yang agak kasar di samping beberapa alat serpih seperti pada lapisan atasnya. Alat tulang masih jarang demikian juga alat litik secara keseluruhan. Fauna besar seperti Bovidae, Cervidae menonjol. Ketebalan lapisan belum diketahui karena masih berlanjut, namun diduga cukup tebal dan berumur hingga puluhan ribu tahun.

Sebagai bandingan, penelitian yang dilakukan oleh Bidang Prasejarah dengan MNHN Perancis di Song Terus telah menampakkan lapisan di bawah Mesolitik yang sangat tebal hingga sekitar 11 meter dari permukaan. Hasil pertanggalan dengan metode U/Th menunjukkan kronologi hunian paling tidak sejak 39.000 tahun yang lalu, bahkan lapisan yang lebih dalam berumur $79.000 \pm 3 \mathrm{BP}$, namun hal ini masih perlu pengujian lanjut. Secara umum hunian gua di Asia Tenggara telah berlangsung sejak akhir Plestosen. Berbagai penemuan seperti di ceruk Lang Rongrien (Thailan), ceruk Tham Khoung (Vietnam), gua Tabon (Filipina), gua Niah (Sarawak), Leang Burung2 (Sulawesi), gua Golo (Maluku) membuktikan hunian gua telah berlangsung sejak 40.000-30.000 tahun yang lalu (Anderson, 1990; Bellwood, 1995; Fox, 1970; Glover, 1981; Tan, 1982).

Rentang waktu antara sekitar awal Holosen hingga 4.500 tahun yang lalu secara umum dikenal sebagai masa perkembangan mesolitik di Indonesia. Dalam kaitannya dengan Gunung Sewu, berbagai hasil pertanggalan yang diperoleh semakin memperjelas kronologi dan perkembangan budaya pada rentang waktu tersebut. Sebanyak 5 pertanggalan telah diperoleh dari Song Keplek, berkisar antara 8.230 \pm $220 \mathrm{BP}-4.510 \pm 90 \mathrm{BP}$. Empat pertanggalan dari Gua Braholo berada dalam rentang $12.060 \pm 180 \mathrm{BP}-6.620 \pm 110 \mathrm{BP}$. Berdasarkan sebaran vertikal temuan, evolusi 
budaya untuk sementara dapat dijelaskan sebagai berikut. Periode awal mesolitik agaknya berlangsung hingga sekitar 7.500 tahun yang lalu, dicırikan oleh artefak litik yang agak jarang. cenderung besar dan agak kasar. Puncak perkembangan budaya berlangsung di antara $7500-4.000$ tahun vang lalu dicırikan eksploitasi lingkungan yang intensif (infra). Setelah itu neolitik berkembang dengan munculnya teknologi gerabah dan beliung persegi.

Studi palinologı awal yang tclah dilakukan di Gua Braholo baru dapat menjelaskan kondisi umum lingkungan daerah ini pada awal Holosen (Polhaupessy, 1997). Lingkungan tergolong kering dan meripakan padang terbuka yang didominasi beberapa jenis paku-pakuan (Pterydophira). Pohon kclapa juga cukup menonjol terutarna di bagian atas. Beberapa jenis vegetasi lainnya adalah Nypa dan Acrostichum yang merupakan tanaman lingkungan pantal. Biji-bijian yang tampaknya berkaitan langsung dengan susbsistensi adalah kemiri (Alurites mollucan) dan kenari (Canarium $s p)$, tetapi lebih terbatas pada lapisan budaya atas

\section{Gunung Sewu: hunian intensif sejak awal Holosen}

Bagainana corak kchidupan dalam rentang waktu ini menjadi topik substansial dari kertas kerja ini Eksploitasi intensif terhadap sumberdaya lingkungan merupakan fenomena yang paling menonjol dalam hunian Gunung Sewu: eksploitasi terhadap gua dan ceruk untuk berbagai keperluan, cksploitasi terhadap batuan dan eksploitasi terhadap fauna dan flora yang tersedıa di sekitar situs Secara Icbih rinci beberapa karakteristik budaya pada kala tersebut, antara lain: (1) eksploitasi gua dan ceruk untuk berbagai fungsi. (2) subsistensi perburuan, (3) Pemanfaatan biota air, (4) cksploitasi intensif sumberdaya batuan untuk kegiatan industri. (5) Pengembangan industri tulang. tanduk. cangkang (6) aktivitas perapian, (7) penguburan terlipat.

\section{Eksploitasi gua dan ceruk}

Salah satu karakter budaya yang khas pada ar al Holosen di wilayah Gunung Sewu adalah pemanfatan gua dan ceruk secara intensif. Hasil pengamatan pada sebanyak 61 gua dan ccruk di seluruh wilayah Gunung Sewu menunjukkan hampir seluruhnya mengandung indikator hunian, yaitu berupa sısa fauna (termasuk moluska), sisa industri litik, dan sisa gerabah pada lantai atau dinding gua. Beberapa gua yang tidak mengandung temuan permukaan terbacas pada gua sungai bawah tanah dan gua yang telah mengalami deformasi lanjut. Diperkuat olch temuan ekskavasi pada beberapa gua berupa adanya lapisan "anthropic" yang tcbal, kescluruhan temuan di atas membuktikan adanya eksploitasi intensif terhadap gua dan ceruk pada awal Holosen. 


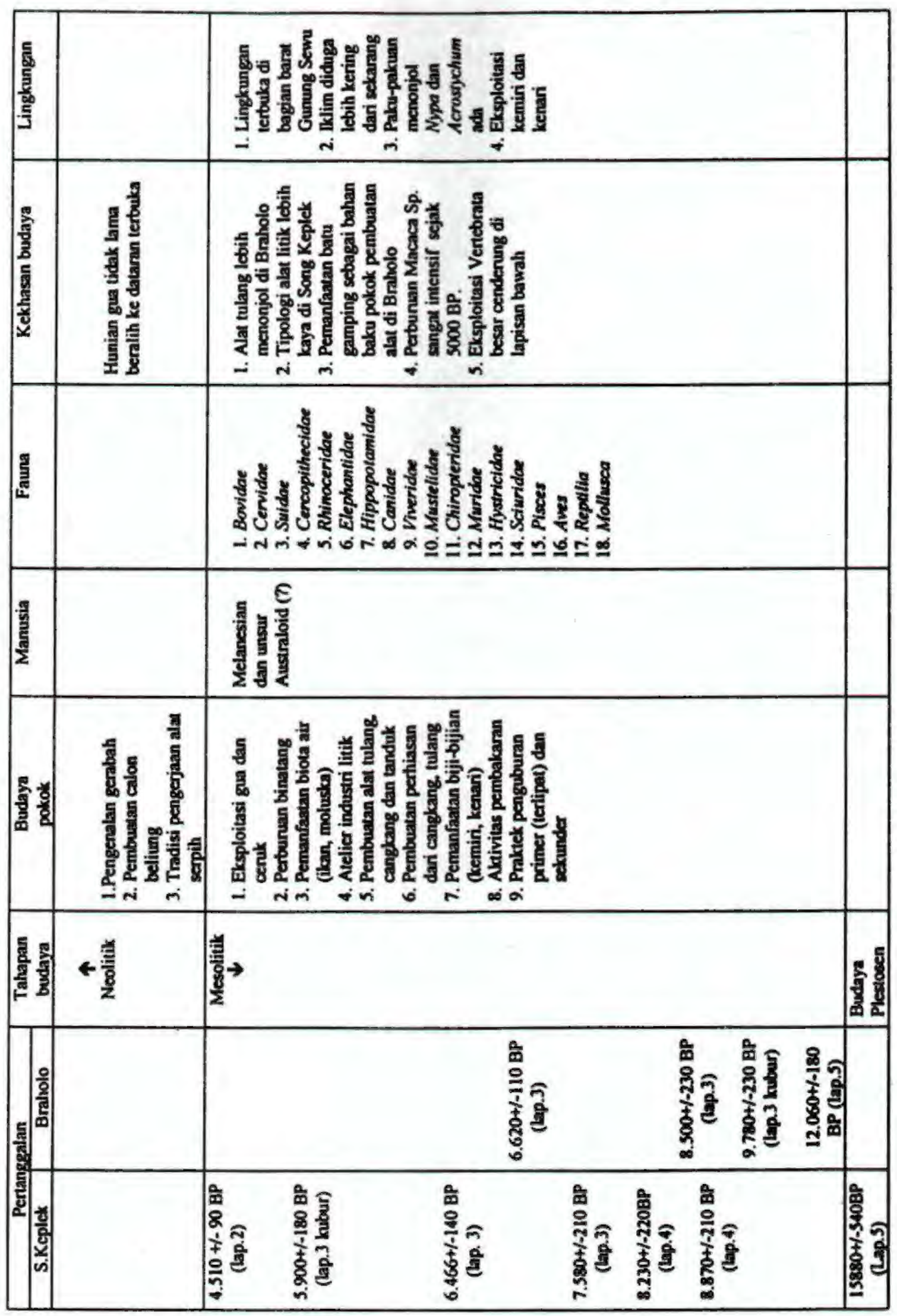


Gua dan cenık merupakan pusat aktivitas untuk beberapa kegiatan, antara lain untuk lokasi kegiatan industri (atélier), lokasi penguburan dan tempat tinggal. Ketiga fungsi ini dapat diamati di Song Keplek. Kegiatan industri berlangsung di bagian selatan mendekati pintu gua. Sisa kegiatan pembuatan alat-alat batu yang terdiri dari serpihan-serpihan buangan (chunks), serpih dipakai. serpih diretus, batu inti dan perkutor tersebar sangat padat, membentuk lapisan setebal 10-15 cm. Di gua Braholo bagian yang mendekati pintu gua (dalam hal ini bagian barat daya) juga difungsikan untuk "atćlier". Serpihan pangkasan yang merupakan produk buangan (waste product), peralatan yang dihasilkan dan peralatan yang digunakan (perkutor) bertumpuk padat di bagian ini.

Pemanfaatan gua untuk tempat penguburan sangat menarik diamati karena berada di sekitar lokasi hunian. Pengamatan sejauh ini menunjukkan keeenderungan pada bagian yang lebih terisolasi, di dekat dinding gua. Di Song Keplek lokasi penguburan mencmpati bagian barat daya yang memanjang di dekat dinding gua. Hal yang serupa di Gua Braholo, tepatnya di bagian barat mendekati dinding gua. Penguburan telah mengenal sistem terlipat yang menunjukkan adanya perlakuan khusus terhadap si mati. Penemuan lepas tulang manusia dan tengkorak di Song Keplek mengisyaratkan adanya penguburan sekunder di samping penguburan primer di atas. Dalam hal ini tengkorak agaknya merupakan bagian tubuh yang terpenting seperti penemuan 3 tengkorak lepas tanpa bagian lain dari gua ini.

Kegiatan bertempat tinggal merupakan kegiatan utama di dalam gua. Sisa kehidupan dan kegiatan sehan-hari ditemukan bercampur di bagian gua lainnya, terutama di bagian tengah. Sisa berbagai jenis binatang buruan, moluska darat, air tawar dan laut merupakan yang terpadat, kemudian sisa peralatan dari batu dan tulang, biji-bijian, dan sisa pembakaran. Keseluruhan temuan tersebut mengisyaratkan adanya berbagai kegiatan yang berlangsung secara teratur dan berkesinambungan di dalam gua, dalam jangka waktu lama.

\section{Subsistensi perburuan}

Pemanfaatan sumberdaya fauna merupakan subsistensi pokok melalui perburuan, seperti tampak pada keragaman dan kepadatan binatang yang ditemukan di dalam gua Hasil detcrminası Pak Rokhus Duc Awe menunjukkan fauna Song Keplek sangat beragam, terdiri dari Bovidae. Cervidae. Suidae. Cercopithecidae, Canidae, Muridae. Viveridae. Rhinoceridae, Elephantidae. Hippopotamidae. Mustelidae. Chiropteridae. Hystricidae, Scuuridae, dll. Selain itu terdapat juga Reptilia (ular dan penyu) dan Aves. Khusus Hippopotamidae dan Canidae (anjing hutan) hingga analisis terakhir belum ditemukan di gua Braholo. 
Sangat menarik mengamati persebaran sisa fauna di Song Keplek di mana pada vertebrata besar (Bovidae, Cervidae, Rhinoceritidae, dll) cenderung pada lapisan bawah (lapisan 5 dan 4) yang agaknya merupakan lapisan di sekitar batas Plestosen. Sebaliknya di lapisan atas, fauna kecil sangat menonjol. Agaknya lingkungan fauna mengalami perubahan yang penting dalam sejarah hunian gua dan diduga berkaitan erat dengan perubahan iklim dan lingkungan vegetasi. Di antara berbagai jenis binatang di atas, kera (Macaca $s p$ ) merupakan jenis yang paling banyak, ditemukan sejak lapisan bawah tetapi jauh lebih padat di lapisan atas. Berdasarkan kepadatannya dapat diduga bahwa kera merupakan binatang buruan utama di kala itu.

\section{Pemanfaatan biota air}

Pemanfaatan biota air cukup menonjol seperti ditampakkan oleh sisa moluska dan ikan. Temuan sisa ikan agak jarang (baru terbatas dari Song Keplek), kemungkinan disebabkan oleh tidak adanya sungai besar yang mengalir sepanjang tahun di daerah ini. Demikian juga telaga yang hanya beberapa yang menyimpan air sepanjang tahun. Jenis moluska sangat bervariasi, terdiri dari Gastropoda, Pelecypoda dan Chephalopoda dari beragam habitat, termasuk habitat darat (tabel.1). Seperti halnya fauna darat, jenis moluska lebih banyak ditemukan di Song Keplek dibanding di Gua Braholo.

\begin{tabular}{||c|c|c|c|c||}
\hline \multicolumn{3}{|c|}{ Gastropoda } & Pelecypoda & \multirow{2}{*}{ Cephalopoda } \\
\hline Darat & Air tawar & Laut & Laut & \\
\hline Achatina sp & Ampularidae & Cypraedae & Veneridae & Nautilidae \\
Amphidromus sp & Lymnaeidae & Haliotidae & Tellinidae & \\
Ciploporidae & Thiaridae & Patellidae & Mytilidae & \\
Operculum & Pelidae & Trochidae & Donacidae & \\
Cyclotus & Ceriithidae & Neritidae & Pectinidae & \\
Elaphrocvonchasp & & Turbinidae & Tridacnidae & \\
Landouriasp & & & & \\
Lagochilus sp & & & & \\
Dyakia Clypeus & & & & \\
Helicinidae & & & & \\
\hline
\end{tabular}

Tabel 2 : Jenis moluska di Song Keplek, Punung.

Keberadaan moluska laut di kedua gua sangat menarik karena jaraknya yang cukup jauh dari pantai. Song Keplek berjarak sekitar $16 \mathrm{~km}$ (garis lurus) dan gua Braholo sekitar $14 \mathrm{~km}$ dari garis pantai Samudera Hindia. Setidaknya dua asumsi dapat dikemukakan di sini. Kemungkinan penghuni kedua gua ini telah mengeksploitasi lingkungan dalam radius yang cukup jauh, hingga daerah pesisir. Di samping berburu binatang darat mereka menangkap ikan dan mencari moluska di sungai, telaga dan 
laut. Kemungkinan lain adalah telah terciptanya hubungan pertukaran antara penghuni pesisir dan pedalaman. Seperti diketahui daerah pesisir juga memiliki gua dan ceruk yang mengandung data hunian, sehingga dapat dikatakan bahwa kedua wilayah ini pernah dihuni secara kontemporer. Pada umumnya jenis temuan (permukaan) pada gua-gua pesisir sama dengan di gua pedalaman. Perbedaan terletak pada komposisi temuan, dimana sisa moluska cenderung lebih banyak di gua pesisir sementara sisa industri litik lebih kaya di pedalaman. Fenomena ini kemungkinan disebabkan karena moluska merupakan subsistensi utama penghuni pesisir yang dipertukarkan dengan produk industri litik penghuni pedalaman. Atau kemungkinan hanya disebabkan eksploitasi terhadap sumberdaya yang tersedia dekat suatu hunian, cenderung lebih intensif dibanding sumberdaya yang jauh.

\section{Eksploitasi sumberdaya batuan}

Keberadaan berbagai batuan di sekitar situs telah melahirkan teknologi litik yang menghasilkan berbagai jenis alat. Kekayaan batu gamping kersikan "rijang" di sekitar Song Keplek mendorong pembuatan alat-alat didominasi jenis batuan ini, sementara jenis batuan lain (jasper, kalsedon, dll) jauh lebih jarang. Dilihat dari warna dan ukuran butiran, gamping kersikan dibedakan menjadi empat kelompok, yaitu: (1) berwarna keputih-putihan dan berbutir halus (agak jarang), (2) berwarna abu-abu atau coklat muda dan berbutir halus (banyak), (3) berwarna abu-abu atau coklat tua dan berbutir kasar (banyak), dan (4) berwarna coklat susu, mengalami proses silikaan lanjut agak transparan (Simanjuntak et.al, 1995). Beberapa lokasi sumber bahan terdekat adalah di sekitar Song Keplek sendiri, gua Klepukiut, Padangan, Mojo, dan Kali Pogog. Lokasi lebih jauh terdapat di berbagai tempat dalam radius $28 \mathrm{~km}^{2}$ (Intan, 1997).

Berlainan dengan di gua Braholo di mana batuan kersikan jarang di sekitarnya mendorong penghuni gua memanfaatkan batu gamping yang tersedia di sekitar gua sebagai bahan pokok pembuatan alat. Dalam hal ini kualitas dan kekerasan batuan tidak lagi menjadi faktor penentu dalam pemilihan bahan, tetapi lebih didasarkan pada ketersediaan bahan. Lokasi batuan kersikan terdekat berjarak sekitar $20 \mathrm{~km}$ di sebelah timur, yaitu di Gelagahan dan Kali Gunung Wiu (Giriwoyo) serta di Kali Oyo (Nglipar). Selebihnya, lebih jauh lagi, terdapat di berbagai lokasi di wilayah kabupaten Pacitan (Intan, 1997).

Teknologi litik umumnya menghasilkan alat-alat serpih dari berbagai tipe, sedangkan alat bilah jauh lebih jarang. Lebih dari 20 tipe alat serpih-bilah telah teridentifikasi di Song Keplek, antara lain serut samping (13 tipe), senut ujung, serut berpunggung tinggi, serut gigir, serut cekung, bor, lancipan, mata panah, gravir, pisau dan "limace" (Simanjuntak et.al, 1994). Di luar keseluruhan tipe tersebut terdapat alat serpih yang 
langsung digunakan tanpa peretusan dalam persentase yang cukup tinggi. Pada umumnya merupakan serpih-serpih yang memiliki sisi lurus dan tajam, sehingga tidak membutuhkan peretusan sebelum digunakan.

Dibanding dengan Song Keplek, tipologi alat serpih yang dihasilkan jauh lebih sedikit di Gua Braholo. Faktor utama penyebabnya adalah bahan baku yang digunakan di gua Braholo didominasi oleh batu gamping, batuan yang lunak dan kurang memungkinkan dikerjakan dalarn berbagai bentuk lewat peretusan. Sebaliknya di Song Keplek, pemakaian batu rijang yang sangat dominan memungkinkan dihasilkannya beragam alat lewat teknik peretusan, karena batuan ini mudah dikerjakan dan sifatnya yang keras sangat baik untuk peralatan. Alat serpih-bilah di atas agaknya bukan merupakan produk baru pada awal Holosen, tetapi besar kemungkinan merupakan lanjutan dari Plestosen Atas. Penemuan lapisan budaya yang diduga Plestosen di bagian bawah serta penemuan-penemuan lain pada gua-gua di Asia Tenggara memperkuat dugaan ini.

Serpih-bilah yang dihasilkan mempunyai bentuk bervariasi, tetapi sebagian besar memanjang. Pada bidang dorsal terdapat 2 atau 3 pangkasan longitudinal menciptakan irisan segi tiga atau trapesium. Dataran pukul sering melebar, tetapi kadang kala sempit atau berfaset. Bulbus dapat berbentuk sangat menonjol atau melebar. Teknik peretusan untuk menciptakan berbagai jenis alat cukup bervariasi dilihat dari keberadaannya (bersambung, acak), kemiringan (landai, terjal), ukuran (marginal, memanjang, melebar), dan lokasi (sisi lateral, distal).

\begin{tabular}{|c|c|c|c|}
\hline \multicolumn{2}{|c|}{ Bahan baku } & \multicolumn{2}{|c|}{ Jenis alat } \\
\hline Song Keplek & Gua Braholo & Song Keplek & Gua Braholo \\
\hline $\begin{array}{l}\text { Rijang } \\
\text { berbagai jenis } \\
\text { (mayoritas), } \\
\text { basalt, fosil } \\
\text { kayu, tufa } \\
\text { kersikan }\end{array}$ & $\begin{array}{l}\text { Gamping } \\
\text { dominan, } \\
\text { menyusul } \\
\text { rijang, basalt, } \\
\text { kalsedon, } \\
\text { kalsit, kuarsa, } \\
\text { meta gamping, } \\
\text { meta basalt }\end{array}$ & $\begin{array}{l}\text { Serut samping, serut } \\
\text { gigir, serut cekung, } \\
\text { serut ujung, bor, } \\
\text { "limace", pisau } \\
\text { berpunggung, mata } \\
\text { panah, batu pipisan, } \\
\text { laneipan, perkutor, } \\
\text { gravir, batu giling, } \\
\text { serpih dipakai }\end{array}$ & $\begin{array}{l}\text { Serut samping, serut } \\
\text { ujung, serut } \\
\text { berpunggung tinggi, } \\
\text { serut cekung, serut } \\
\text { gigir, lancipan, batu } \\
\text { pelandas, batu } \\
\text { pipisan, batu asah, } \\
\text { batu giling, perkutor }\end{array}$ \\
\hline
\end{tabular}

Tabel 3: Bahan baku dan jenis alat di Gua Braholo dan Song Keplek.

\section{Pengembangan industri tulang, cangkang, dan tanduk}

Penghuni Song Keplek dan Gua Braholo di samping mengembangkan teknologi litik juga industri tulang secara bersamaan. Persebaran sisa industri kedua jenis bahan yang 
selalu berasosiasi satu sama lain, membuktikan tidak adanya dikotomi antara keduanya, tetapi cenderung sebagai produk bersama. Kedua jenis produk teknologi inilah yang paling menonjol dari budaya Holosen Gunung Sewu, baik secara kuantitas maupun kualitas. Industri tulang merupakan karakter budaya paling khas dilihat dari keberadaannya dan jenis-jenis yang dihasilkan. Umumnya merupakan spatula, lancipan dan jarum dalam berbagai tipe di samping tulang-tulang yang menunjukkan bekas pengerjaan (Bagyo Prasetyo, 1996). Proses pembuatan menerapkan teknik pangkasan untuk membelah tulang diikuti oleh teknik penggosokan untuk meratakan permukaan (Simanjuntak, 1996).

Gua Braholo menampilkan produk khas, yaitu jarum yang secara tipologis dibedakan menjadi jarum lancipan tunggal dan lancipan ganda Bagyo Prasetyo, 1997). Bahan pembuatannya tidak mengacu pada jenis tulang tertentu, tetapi cenderung dari berbagai jenis, seperti tulang kering, tulang panjang, tulang jari, tulang lengan dan tanduk. Hal yang sama dengan jenis binatangnya sangat bervariasi, antara lain Macaca sp. Cervidae, Canidae, Bovidae dan Suidae. Keragaman jenis tulang dan jenis binatang tersebut menunjukkan adanya pemanfaatan intensif terhadap tulang-tulang yang tersedia. Jarum lancipan ganda merupakan jenis yang paling menonjol dari yang lain. Pada umumnya berukuran kecil dengan panjang berkisar $3 \mathrm{~cm}$. Jarum terpendek adalah $1,6 \mathrm{~cm}$ dan terpanjang mencapai $8,8 \mathrm{~cm}$. Lancipan ganda dapat dibuat dari sepotong tulang utuh yang menghasilkan jarum berlubang di tengah, tetapi paling sering dari pecahan tulang sehingga menghasilkan jarum masif. Pembuatan lancipan dilakukan dengan penggosokan sisi keliling bagian ujung hingga tercipta lancipan simetris atau asimetris. Jarum dengan lancipan ganda ini mengingatkan kita pada lancipan Muduk yang ditemukan pada gua-gua di Sulawesi Selatan (Heekeren, 1972) dan pernah juga dilaporkan dari Song Gentong, Tulung Agung (Marliac dan Simanjuntak, 1996). Perbedaannya dapat terlihat pada ukurannya yang lebih kecil dan kuantitasnya yang sangat menonjol.

Mengenai fungsi jarum belum dapat dipastikan, namun setidaknya ada 3 asumsi penggunaan, yaitu: (1) sebagai alat pencungkil isi kerang untuk dimakan, (2) sebagai alat penangkap ikan, dan (3) sebagai alat penjahit atau pelubang. Asumsi pertama lebih memungkinkan karena didukung oleh temuan cangkang moluska yang banyak. Diduga cangkang ini merupakan sisa makanan yang terbuang setelah isinya dimakan lewat pencungkilan. Asumsi kedua kurang kuat karena di lingkungan gua tidak terdapat sungai besar, kecuali telaga. Selain itu sisa ikan juga kurang menonjol dalam himpunan sisa fauna gua Braholo. Asumsi ketiga lebih sulit dibuktikan karena bahan yang mudah hancur termakan waktu.

Spatula merupakan jenis alat yang umum di Gunung Sewu, biasanya dibuat dari tulang panjang Bovidae dan Cervidae yang dibelah. Tajaman lebar yang merupakan ciri khasnya dibuat lewat pemangkasan monofasial atau bifasial, dilanjutkan dengan 
penggosokan permukaan. Untuk mengeraskan alat (khususnya bagian tajaman) dilakukan dengan cara memanaskannya (pembakaran) ke api. Seperti spatula, lancipan juga merupakan produk umum industri tulang Gunung Sewu. Dibuat dari tulang panjang, pengerjaan lancipan dapat melalui salah satu atau kedua sisinya. Sebagian di antaranya mempunyai permukaan yang digosok halus, sedangkan lainnya dibiarkan kasar. Dalam hal alat ini dibuat dari segmen tulang panjang besar, bagian dalam tulang masih melengkung. Alat lain yang khas dari gua Braholo adalah alat dari tanduk rusa dengan salah satu cabangnya dikerjakan lewat penajaman. Umumnya merupakan tanduk rusa sembelihan dan hal ini memperkuat dugaan adanya kegiatan perburuan. Tajaman melebar diciptakan dengan cara penajaman dari satu bidang dan bagian pangkal disiapkan untuk tempat ikatan tangkai.

Alat dari cangkang lebih banyak dan lebih bervariasi di Song Keplek. Mayoritas termasuk alat serut yang dihasilkan dari pecahan bagian luar cangkang dan kemudian diretus teratur. Alat yang tergolong lancipan dihasilkan dengan cara melancipkan salah satu atau kedua ujungnya, ditemukan di Song Keplek dan agak jarang di gua Braholo. Jenis lainnya adalah alat pengupam yang dibuat dari pecahan cangkang Veneridae, dicirikan oleh salah satu sisi cembung yang diciptakan untuk penggosokan dan keberadaan kilapan pada salah sisi tersebut akibat aktivitas penggosokan (Bagyo Prasetyo, 1997). Pemanfaatan cangkang lainnya adalah untuk perhiasan dengan cara melubanginya. Cangkang yang digunakan biasanya jenis moluska laut yang secara natural telah mengkilap. (Pelecypoda dari famili Arcidae dan Oyster di samping Operculum). Melalui pemangkasan dihasilkan berbagai bentuk (bulat, lonjong, tidak beraturan, dll) dengan sisi keliling yang dihaluskan lewat penggosokan. Bagian tengah dilubangi dengan teknik bor atau cungkil.

\section{Aktivitas perapian}

Aktivitas perapian sangat menonjol dalam hunian Song Keplek dan Gua Braholo, seperti tampak pada ketebalan lapisan yang mengandung sisa pembakaran. Di gua Braholo lapisan ini sangat menonjol, mencapai ketebalan sekitar 200 meter (lapisan 3). Di bawah lapisan ini terdapat kubur manusia berumur sekitar 9.000 tahun dan diperkirakan berkesinambungan hingga sekitar 4.000 tahun yang lewat. Pada lapisan ini dibentuk oleh satuan-satuan perapian yang dicirikan oleh lempung terbakar kemerah-merahan di bagian bawah, abu pembakaran dan arang di bagian atas. Masing-masing satuan diperkirakan berlangsung dalam rentang waktu tertentu. Di Song Keplek lapisan perapian paling jelas tampak pada kotak B6 yang mencapai ketebalan sekitar meter. Pertanggalan bagian bawah lapisan ini sekitar 7.500 tahun yang lalu dan diperkirakan berlangsung hingga sekitar 4.500 tahun. 
Hal yang menarik dikemukakan bahwa dalam lapisan perapian banyak sisa fauna dan artefak terbakar. Gejala ini dapat terjadi karena faktor kebetulan dimana secara tidak sengaja berbagai benda yang berada di sekitar perapian ikut terbakar. Tetapi di sisi lain kemungkinan karena faktor kesengajaan: tulang-tulang terbakar karena berkaitan dengan pengelolaan bahan makanan, alat-alat tulang berkaitan dengan upaya pengerasan, dan tinggalan lainnya berkaitan dengan upaya pemusnahan. Suatu hal yang pasti keberadaan lapisan ini membuktikan perapian merupakan aktivitas penting dalam hunian gua. Selain berhubungan dengan pengolahan bahan makanan, perapian dapat berfungsi untuk memanaskan ruangan dan untuk perlindungan dari gangguan binatang. Dalam masyarakat yang lebih maju perapian juga dimaksudkan untuk pemusnahan sampah.

\section{Aktivitas penguburan}

Penemuan sisa manusia, lepas atau dalam struktur anatomis, memberikan gambaran tentang pendukung budaya Holosen Gunung Sewu. Sisa manusia dari Song Keplek meliputi sebuah rangka (kubur primer) dalam anatomi lengkap, 3 tengkorak lepas dan beberapa tulang lepas. Sementara dari gua Braholo berupa sebuah rangka, juga dalam struktur anatomis lengkap dan beberapa tulang lepas. Baik rangka di Song Keplek maupun di gua Braholo sama-sama menunjukkan penguburan terlipat dengan beberapa variasi lokal. Di Song Keplek mayat dikubur dalam posisi miring, pada arah barat laut- tenggara. Kepala terletak di selatan menghadap ke timur. Tangan kanan terlipat dengan jari-jari menyentuh pipi dan tangan kiri terlipat di dada. Kedua kaki terlipat dengan tumit menyentuh pinggul. Tidak terlihat adanya bekal kubur, selain fragmen-fragmen tulang dan serpih-serpih rijang di sekitar kubur. Hasil pertanggalan Cl4 terhadap arang dari sekitar kubur menunjukkan kubur ini berumur 5.900 $180 \mathrm{BP}$.

Kubur dari gua Braholo berada pada lapisan berumur $9.780 \pm 230$ BP, sekitar 4.000 tahun lebih tua dari mayat Song Keplek. Kubur ini terletak di bawah lapisan perapian yang sangat tebal. Mayat dikuburkan dalam posisi terlentang pada arah timur-barat dengan kepala terletak di barat. Kedua kaki terlipat dengan tumit mendekati pinggul, tangan kiri terlipat menempel di dada dan tangan kanan lurus menyentuh lutut. Di atas dada hingga perut terdapat blok batu yang agaknya sengaja disusun untuk menutupi mayat. Diduga untuk melindungi mayat dari gangguan binatang atau untuk mencegah rohnya meninggalkan badan. Sistem semacam ini ditemukan pada gua Cha di Malaysia dan gua Sai Yok di Thailand (Heekeren, 1972) dan baru-baru ini ditemukan di gua Marjan (Nurani, 1997). Seperti di Song Keplek tidak tampak adanya bekal kubur, kecuali fragmen-fragmen tulang dan artefak litik di sekitarnya.

Sistem penguburan terlipat agaknya berkembang luas sejak awal Holosen. Penemuan pertama dilaporkan di gua Lawa, Sampung, Ceruk Sodong dan Gua Marjan 
(Heekeren, 1972; Nurani, 1997). Kubur terlipat lainnya baru-baru ini ditemukan di Song Gentong, Tulungagung. Di sini mayat dikuburkan pada arah barat laut tenggara, dalam posisi miring ke kiri dengan kepala di barat laut. Kedua kaki terlipat ke arah pinggul, sementara kedua tangan diletakkan di bawah dagu. Bekal kubur berupa hematit berbentuk bola, di dekat kaki dan bubukan hematit di sekitar rangka, diduga sengaja ditaburkan. Lapisan pengandung kubur ini bertanggal 7.090 \pm 70 BP (Marliac dan T.Simanjuntak, 1996).

Penemuan kubur-kubur manusia dari berbagai situs di atas menunjukkan penghuni seluruh wilayah ini merupakan pendukung budaya yang sama. Penguburan dengan sistem terlipat membuktikan adanya perlakuan khusus terhadap si mati. Sebagian ahli menganggap posisi terlipat sebagai tiruan bayi di dalam kandungan, melambangkan kelahiran kembali pada kehidupan sesudah mati (Soejono, 1977). Namun sebagian lainnya meragukan anggapan ini dan lebih mendasarkan pada alasan praktis, yaitu tempat penguburan yang sempit, seperti pada sarkofagus.

\begin{tabular}{|c|c|c|c|}
\hline Gua/Ceruk & Sikap mayat & Pertanggalan & Bekal kubur \\
\hline $\begin{array}{l}\text { Song Keplek, } \\
\text { Punung }\end{array}$ & $\begin{array}{l}\text { Miring ke kanan, barat laut- } \\
\text { tenggara dengan kepala di } \\
\text { tenggara, kaki terlipat dengan } \\
\text { tumit mendekati pinggul, } \\
\text { tangan kanan menyentuh } \\
\text { pipih, tangan kiri di dada. }\end{array}$ & $5.900 \pm 180 \mathrm{BP}$ & - \\
\hline $\begin{array}{l}\text { Gua Braholo, } \\
\text { Wonosari }\end{array}$ & $\begin{array}{l}\text { Terlentang, timur-barat } \\
\text { dengan kepala di barat, kaki } \\
\text { terlipat mendekati pinggul, } \\
\text { tangan kiri di dada dan } \\
\text { tangan kanan menyentuh } \\
\text { lutut, ditutupi batu. }\end{array}$ & $9.780 \pm 230 \mathrm{BP}$ & - \\
\hline $\begin{array}{l}\text { Song Gentong, } \\
\text { Tulungagung }\end{array}$ & $\begin{array}{l}\text { Miring ke kiri, barat laut- } \\
\text { tenggara dengan kepala di } \\
\text { barat laut, kaki terlipat } \\
\text { dengan tumit mendekati } \\
\text { pinggul, tangan terlipat dekat } \\
\text { perut }\end{array}$ & $8.760 \pm 70 \mathrm{BP}$ & $\begin{array}{l}\text { Hematit ditaburi dan } \\
\text { dalam bentuk bola }\end{array}$ \\
\hline $\begin{array}{l}\text { Gua Lawa, } \\
\text { Ponorogo }\end{array}$ & $\begin{array}{l}\text { Terlentang, tangan kanan di } \\
\text { bawah dagu, lutut terlipat ke } \\
\text { arah dagu. }\end{array}$ & - & \\
\hline $\begin{array}{l}\text { Ceruk Sodong, } \\
\text { Puger }\end{array}$ & $\begin{array}{l}\text { Terlentang, kaki terlipat, } \\
\text { tangan kanan di atas perut. }\end{array}$ & - & \\
\hline $\begin{array}{l}\text { Gua Marjan, } \\
\text { Puger }\end{array}$ & $\begin{array}{l}\text { Terlentang, kaki terlipat, } \\
\text { timur-barat dengan kepala di } \\
\text { timur, ditutupi batu. }\end{array}$ & - & \\
\hline
\end{tabular}

Tabel 4: Data kubur terlipat (flexed position) di Jawa Timur 


\section{Budaya awal Holosen Gunung Sewu: salah satu sub kelompok budaya Jawa Timur}

Gunung Sewu sebagai suatu kesatuan geografis yang dicirikan oleh keberadaan ribuan bukit karst menampilkan sejarah kehidupan manusia yang khas sejak awal Holosen. Kesatuan geografis dengan kesamaan sumberdaya pokok yang dimiliki mendorong tumbuhnya budaya yang mengandalkan eksploitasi lingkungan. Penghuni awal Holosen Gunung Sewu adalah manusia yang mengeksploitasi berbagai relung alam untuk berbagai keperluan, terutama untuk hunian, penguburan dan kegiatan industri. Keberadaan berbagai jenis batuan membuka berkembangnya teknologi litik untuk menghasilkan alat serpih-bilah. Keberadaan sumberdaya fauna di daerah sekitar melahirkan subsistensi perburuan. Keragaman sisa fauna pada gua-gua hunian menunjukkan bahwa perburuan tidak terbatas pada suatu jenis tertentu, tetapi beragam binatang yang tersedia. Keberadaan lapisan perapian yang tebal di dalam gua agaknya berkaitan dengan pengolahan binatang buruan sebagai bahan makanan, seperti terlihat pada banyaknya tulang-tulang terbakar. Tulang-tulang binatang ini pula yang dimanfaatkan untuk berbagai peralatan dan yang melahirkan industri khas dengan berbagai jenis peralatan. Subsistensi perburuan juga diikuti dengan penangkapan ikan atau biota air, baik pada air tawar, maupun di laut. Berbagai jenis moluska menjadi bukti pemanfaatan tidak hanya sebagai bahan makanan tetapi juga untuk berbagai peralatan dan perhiasan.

Budaya bagian timur dan barat Gunung Sewu menampakkan beberapa kekhasan lokal di samping kesamaan budaya pokok seperti di atas. Kekhasan tersebut banyak dipengaruhi oleh sumberdaya lingkungan yang tersedia. Produk jarum lancipan ganda yang padat, alat-alat dari batu gamping merupakan unsur budaya khas di bagian barat (gua Braholo) yang hampir tidak ditemukan di bagian timur (Song Keplek). Sebaliknya kekayaan tipo-teknologi produk industri litik dan alat pengupam dari cangkang kerang merupakan unsur budaya khas di Song Keplek. Sistem penguburan terlipat dengan posisi terlentang dianut di gua Braholo, sedangkan di Song Keplek menerapkan sistem penguburan terlipat dalam posisi miring.

Budaya Gunung Sewu agaknya merupakan suatu sub kelompok budaya yang mempunyai wilayah eksploitasi di sekitar perbukitan karst. Unsur-unsur budaya yang dimiliki menampakkan kesamaan dengan budaya kontemporer di satuan-satuan perbukitan gamping lainnya di Jawa Timur. Dilihat dari satuan geografis perbukitan karst, setidaknya terdapat sebanyak 7 sub kelompok budaya awal Holosen di seluruh Jawa Timur, yaitu Gunung Sewu, Ponorogo, Tulungagung, Tuban, Bojonegoro, Situbondo, dan Jember. Keseluruhannya menampakkan kesamaan budaya pokok, antara lain eksploitasi intensif sumberdaya lingkungan, pengembangan teknologi litik dan tulang (termasuk tanduk dan cangkang) yang khas. Dalam konteks Nusantara budaya ini membentuk kelompok tersendiri dengan wilayah persebaran yang terbatas, 
di luar kelompok Hoabinhian di pesisir timur bagian timur Sumatra, kelompok lukisan gua di bagian timur Indonesia dan kelompok serpih-bilah dengan persebaran yang lebih luas dan merata (Simanjuntak, 1994).

Suatu hal yang menarik diingatkan bahwa budaya awal Holosen Gunung Sewu agaknya telah berakar pada masa Plestosen Atas. Beberapa indikasi mendukung dugaan ini, antara lain penemuan lapisan budaya Preholosen pada gua-gua yang diteliti hingga kedalaman yang belum diketahui. Penemuan ini sejalan dengan penemuan serupa pada gua-gua di Asia Tenggara daratan dan kepulauan, dengan pertanggalan hunian sejak 40.000 tahun yang lalu hingga kala Holosen (Simanjuntak, 1996). Indikasi lainnya adalah keberadaan industri serpih-bilah sebagai salah satu unsur budaya pokok. Industri ini telah berkembang sejak akhir Plestosen dan berlanjut di berbagai situs di Asia Tenggara sebagai tradisi hingga Holosen. Industri serpihbilah Gunung Sewu agaknya merupakan tradisi yang berkembang sejak akhir Plestosen. Penelitian-penelitian mendatang diharapkan dapat memberi jawaban tentang budaya Plestosen Atas yang merupakan akar budaya Holosen di Gunung Sewu.

\section{KEPUSTAKAAN}

Anderson, Douglas D., 1990, Lang Rongrien Rockshelter: a Pleistocene-Early Holosen Archaeological Site From Krabi, Southwestern Thailand, Philadelpia: The university Museum.

Bagyo Prasetyo, 1996, Hasil analisis alat tulang dan kerang Song Keplek, Punung, (laporan belum diterbitkan)

-.-.---, 1997, Hasil analisis alat tulang Gua Braholo, Gunung Kidul, (laporan belum diterbitkan)

Bellwood, Peter, 1995, Archaeological Research in the Northern Molluccas 19911994, A Preliminary Report.

Bemmelen, R.W.van, 1949, The Geology of Indonesia, vol.1A, The Hague: Martinus Nijhoff

Fox.R., 1970, Tabon Caves, Natinal Museum Monograph, 1, Manila.

Glover, I.G, 1981, "Leang Burung 2: An Upper Palaeolithic Rock Shelter in South Sulawesi", Modern Quaternary Research in Southeast Asia, 6: 1-38. 
Gorman, Chester, 1971, "The Hoabinhian and after: Subsistence Pattern in Southeast Asia during the late Pleistocene and Early recent periods", World archaeology, 2 (3), p.300-320.

Ha Van Tan, 1985, "The Late Pleistocene climate in Southeast Asia: new data from Vietnam", Modern Quaternary research in Southeast Asia, 9, Rotterdam: A.A.Balkema, p.81-86.

Harrison, Tom, 1957, "The Great Cave of Niah: a Preliminary Report of Bornean Prehistory", Man, 57, p.161-166

Heekeren, H.R. van, 1972, The Stone Age of Indonesia, Verhandelingen KITLV, XXI, 's-Gravenhage.

Intan, S.Fadhlan, 1996, Geologi Situs-situs Prasejarah Gunung Sewu, (laporan penelitian belum diterbitkan)

------, 1997, Geologi situs Gua Braholo, Kecamatan Rongkop, Gunung Kidul, (laporan penelitian belum diterbitkan)

Nurani, Indah Asikin, 1997, Pola Pemanfaatan lahan gua pada komunitas gua Gunung Watangan tahap V, Laporan Hasil Penelitian Arkeologi (belum terbit)

Polhaupessy, Netty, 1997, Laporan singkat analisis palinologi Gua Braholo, Gunung kidul, (tidak diterbitkan)

Retno Handini, 1996, Laporan Penelitian Song Keplek, Punung (Kabupaten Pacitan), (belum diterbitkan)

-.n--, 1997, Laporan penelitian gua Braholo, Kabupaten Gunung Kidul, (belum diterbitkan)

Sartono, S., 1964, Stratigraphy and sedimentation of the Eastern most part of Gunung Sewu (East Java), Thesis, Bandung.

Semah, Francois, et.al., 1990, Mereka Menemukan Pulau Jawa. Jakarta: Puslit. Arkenas.

Simanjuntak, Truman, 1993, "The Identity of the Mesolithic in the Pegunungan Seribu", International Conference on Human Paleoecology, Jakarta: LIPI 
Simanjuntak, Truman, 1994, "Pegunungan Seribu: sejarah Hunian yang Panjang", Kertas Kerja pada Ceramah Ilmiah di Pemda Pacitan.

--a---, 1996a, "Cave habitation during the Holocene Period in Gung Sewu", Aspek Arkeologi no. 18, Jakarta: Puslit Arkenas

----, 1996b, "Mésolithic de l'Indonésie: une hétérogénéité culturelle", l'Anthropologie (Paris), tome 99, no.4, 626-636.

-----, "Song Keplek and Song Terus Caves: A New Insight For the Prehistory of Gunung Sewu", inpress.

Simanjuntak, Truman, François Sémah, Anne-Marie Sémah, Hubert Forestier, 1994, "Chronologie da la Préhistoire Indonésienne: Recentes Reserches Progress sur les Montagnes du Sud de Java", kertas kerja pada Kongres EurASEAA, Paris, (inpress):

Simanjuntak, Truman, Hubert Forestier, Dubel Driwantoro, 1995, Studi Pendahuluan Tentang Industri Litik dari Song Keplek, Punung, inpress

Soejono, R.P. (ed.), 1984, Sejarah Nasional Indonesia I, Jakarta: P.N. Balai Pustaka

-------, (1977), Sistem-sistem penguburan pada akhir masa prasejarah di Bali, Jakarta, Desertasi

Widianto, Harry, 1994, Laporan Analisis Sisa Komponen Manusia Dari Song Keplek, Punung (Pacitan), Tidak Diterbitkan. 


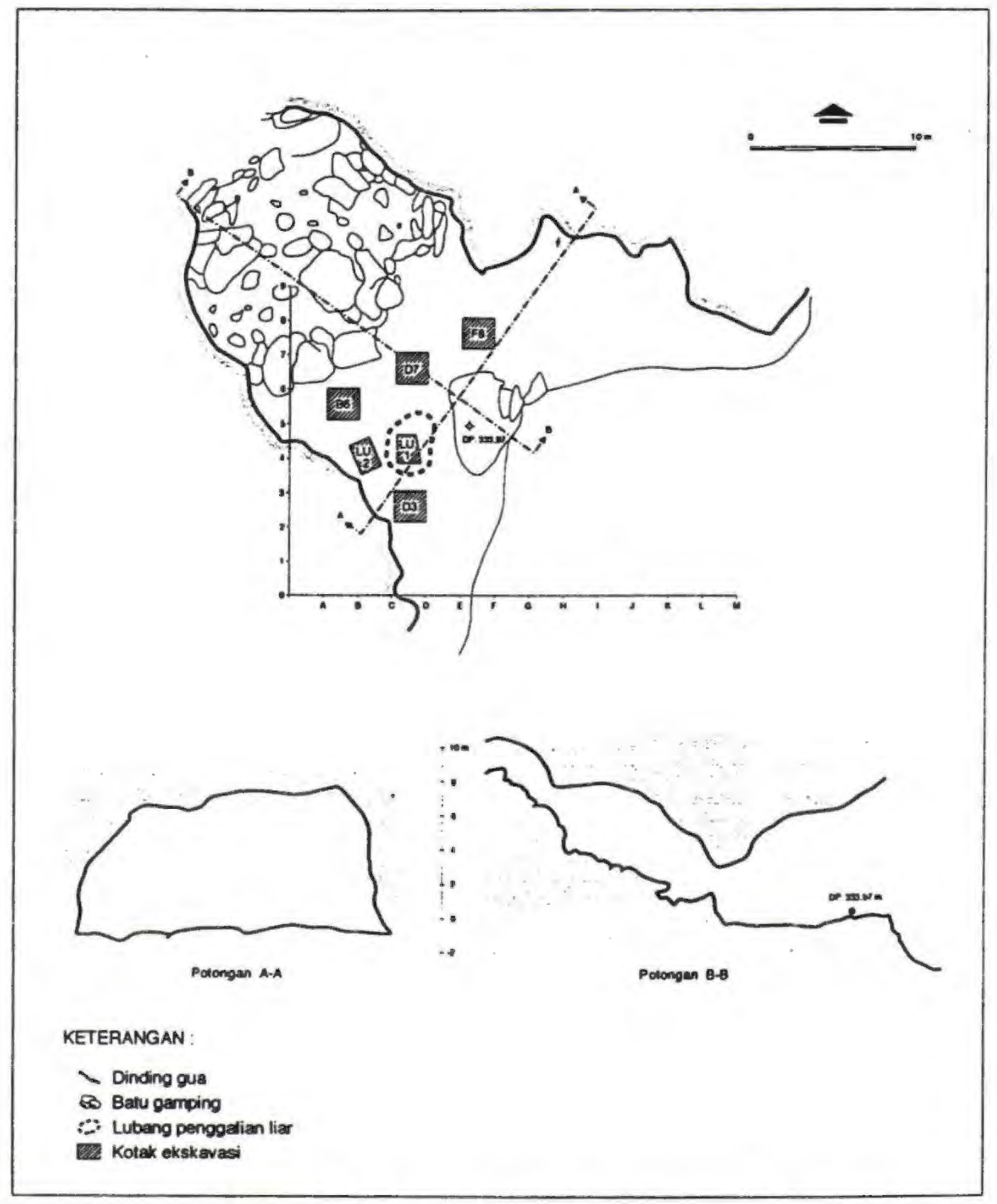

Gambar 1 : Denah dan irisan Song Keplek, Punung (Jawa Timur) 


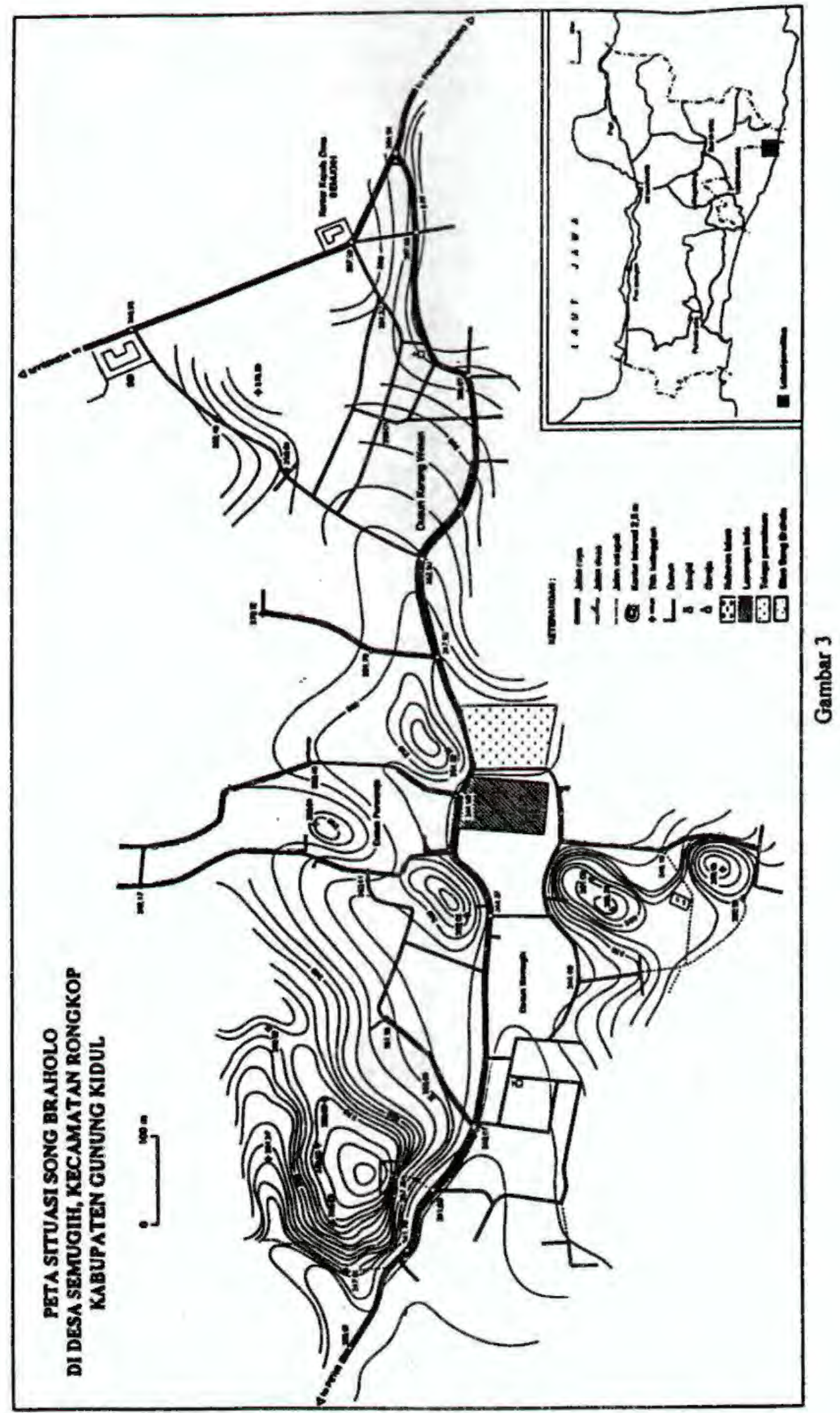

Berkala Arkeologi Th. XIX (I) 


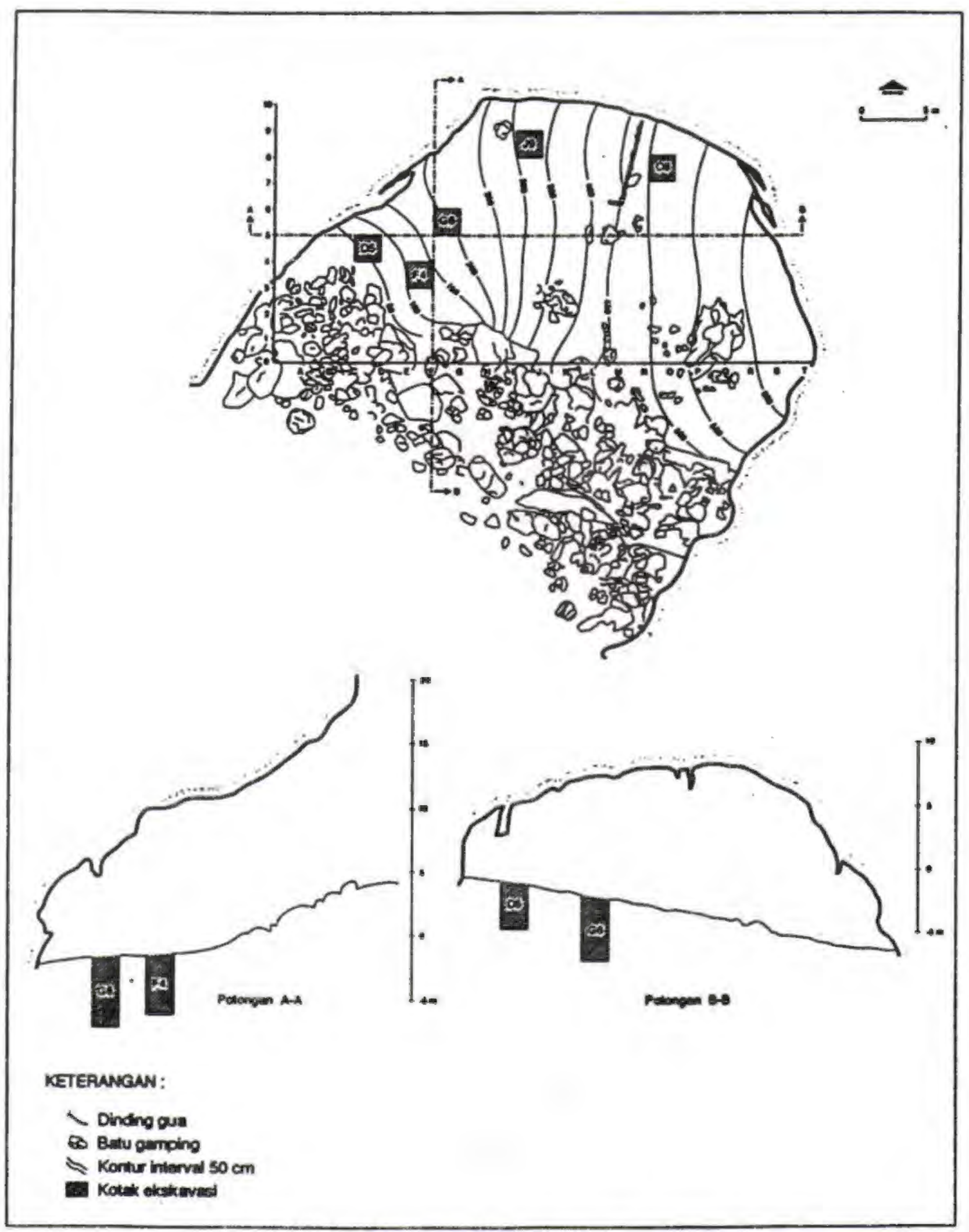

Gambar 2 : Denah dan irisan Gua Braholo, Baran (D.I. Yogyakarta) 